\title{
Quantitative carcass characteristics and quality of shoulder and loin of crossbred goat kids receiving diets with live yeast (Saccharomyces cerevisiae var. boulardii)
}

\section{Características quantitativas da carcaça e qualidade da paleta e do lombo de cabritos mestiços recebendo dietas com levedura viva (Saccharomyces cerevisiae var. boulardii)}

\begin{abstract}
Fernanda Maraquena Soares Pili'; Cibele Regina Schneider ${ }^{2}$; Caroline Isabela da Silva3; Giovana da Silva Oliveira ${ }^{4}$; Jennifer Braga Altero ${ }^{4}$; Vanessa Duarte ${ }^{1}$; Claudete Regina Alcalde ${ }^{5 *}$
\end{abstract}

\section{Highlights}

We studied the effects of live yeast on carcass characteristics of goat kids.

Live yeast supplementation did not influence quantitative carcass characteristics.

Sex had an effect on the carcass yield of crossbred goat kids.

The inclusion of live yeast had no effect on the yield of commercial cuts.

\section{Abstract}

The objective of this study was to evaluate the influence of live yeast (Saccharomyces cerevisiaevar. boulardii) on the quantitative and qualitative characteristics of the shoulder and loin of Boer $x$ Saanen crossbred goat kids. Twenty-seven carcasses were used, 13 females and 14 uncastrated males with an average age of 192 days, weighing $30.76 \mathrm{~kg}$, distributed in a completely randomised design using a $2 \times 2$ factorial arrangement (diet and sex). The yeast was added to the feed before pelletising in a proportion of $0.050 \mathrm{~g} / \mathrm{kg}$ dry matter (DM). When the goats reached an average of $30 \mathrm{~kg}$ of live weight, they were slaughtered. No effects of live yeast on quantitative carcass and qualitative characteristics of shoulder and loin were observed. Regarding sex, males had higher slaughter weights $(31.73 \mathrm{~kg})$, empty carcass weight $(27.98 \mathrm{~kg})$, hot carcass weight $(14.39 \mathrm{~kg})$, cold carcass weight $(14.22 \mathrm{~kg})$, higher carcass compactness index $(0.28 \mathrm{~kg} / \mathrm{cm})$, lower slaughter age (176 days) and lower cooling loss (1.20\%). For the cut yields, females presented a higher loin yield (11.55\%) and males presented a higher neck yield (6.84\%). In the shoulder, males presented a higher

1 M.e of Animal Science, Universidade Estadual de Maringá, UEM, Maringá, PR, Brazil. E-mail: fernandapili@hotmail. com; va.duarte114@gmail.com

2 PhD Student of Animal Science, UEM, Maringá, PR, Brazil. E-mail: cibeleregina17@hotmail.com

${ }_{3}^{3}$ PhD Student of Food Science, UEM, Maringá, PR, Brazil. E-mail: carolineisabeladasilva@hotmail.com

${ }^{4}$ Animal Scientist, UEM, Maringá, PR, Brazil. E-mail: gihholiveira_@hotmail.com; jeny_alter08@hotmail.com

${ }_{5}$ PhD, Profa of Animal Science, UEM, Maringá, PR, Brazil. E-mail: cralcalde@wnet.com.br

* Author for correspondence

Received: May 19, 2021 - Approved: July 22, 2021 
proportion of bone (18.58\%), while females presented a higher proportion of fat (17.09\%) and muscle:bone (3.47). In the loin, females showed higher fat deposition (19.54\%) in relation to males. The inclusion of yeast Saccharomyces cerevisiae var. boulardii in the crossbred goat kids' diet did not generate differences in the quantitative and qualitative characteristics of the shoulder and loin.

Key words: Commercial cuts. Meat quality. Probiotic. Sex.

\section{Resumo}

O objetivo deste estudo foi avaliar a influência da levedura viva (Saccharomyces cerevisiae var. boulardii) sobre as características quantitativas e qualitativas da paleta e do lombo de cabritos mestiços Boer $\mathrm{x}$ Saanen. Foram utilizadas 27 carcaças, 13 fêmeas e 14 machos não castrados com idade média de 192 dias e peso de $30,76 \mathrm{~kg}$, distribuídas em delineamento inteiramente casualizado em esquema fatorial 2 x 2 (dieta e sexo). A levedura foi adicionada à ração antes da peletização na proporção de $0,050 \mathrm{~g} / \mathrm{kg}$ de MS. Quando os cabritos atingiram a média de $30 \mathrm{~kg}$ de peso vivo, os animais foram abatidos. Não foram observados efeitos da levedura viva na carcaça quantitativa e nas características qualitativas da paleta e do lombo. Em relação ao sexo, os machos apresentaram maiores pesos de abate $(31,73 \mathrm{~kg})$, peso de carcaça vazia $(27,98 \mathrm{~kg})$, peso de carcaça quente $(14,39 \mathrm{~kg})$, peso de carcaça fria $(14,22 \mathrm{~kg})$, maior índice de compacidade de carcaça $(0,28 \mathrm{~kg} / \mathrm{cm})$, menor abate idade (176 dias) e menor perda por resfriamento (1,20\%). Para os rendimentos de cortes, as fêmeas apresentaram maior rendimento de lombo $(11,55 \%)$ e os machos apresentaram maior rendimento de pescoço (6,84\%). Na paleta, o sexo masculino apresentou maior proporção de osso (18,58\%), enquanto o feminino apresentou maior proporção de gordura $(17,09 \%)$ e músculo: osso $(3,47)$. No lombo, as fêmeas apresentaram maior deposição de gordura $(19,54 \%)$ em relação aos machos. A inclusão da levedura Saccharomyces cerevisiae var. boulardii na dieta de cabritos mestiços não expressa diferenças nas características quantitativas e qualitativas da paleta e do lombo.

Palavras-chave: Cortes comerciais. Probiótico. Qualidade da carne. Sexo.

\section{Introduction}

For goat production systems, the quantitative characteristics of the carcass and the qualitative characteristics of the meat are fundamental, as they allow the identification and prioritization of animals with better carcasses (Liotta, Chiofalo, Lo Presti, \& Chiofalo, 2020), besides representing the fraction with the highest commercial value.

The main challenge of beef goat farming is the search for animals capable of metabolising nutrients for higher muscle production and better carcass quality, ensuring meat juiciness and tenderness (Marques et al.,
2013). Thus, specific breeds have been used, like Boer as the paternal breed in crosses with females of other breeds, generating offspring with carcasses of superior quality, due to the acceleration of weight gain, precocity and better feed conversion (Cartaxo et al., 2014).

The goat species has carcass yields ranging from $40 \%$ to $54 \%$ (Cartaxo et al., 2014; Gomes et al., 2011; Salles et al., 2013) and its fat, about $50 \%$ to $60 \%$, is located in the abdominal region (Marques et. al., 2013). Some factors such as breed, sex and age, influence muscle development, fat quantity and distribution, interfering with meat quality (Pophiwa, Webb, \& Frylinck, 2020). 
The use of additives in animal nutrition stimulates growth and weight gain, improving feed efficiency (Rai, Yadav, \& Lakhani, 2013). Probiotics are living microorganisms-based food additives, which when added to animal feed in small doses, according to Uyeno, Shigemori and Shimosato (2015), can have beneficial effects.

Commercially, fungi such as the Saccharomyces species live yeast are the most commonly used in ruminant nutrition (Uyeno et al., 2015), as some Saccharomyces cerevisiae strains influence daily consumption, milk and meat production, digestibility, among other benefits.

Live yeast Saccharomyces cerevisae var. boulardii has been used in animal feed to act on the balance of the intestinal microbiota by stimulating beneficial microflora (Uyeno et al., 2015), in addition to improving the animals' immunity (Kayser et al., 2019).

The objective of this work was to evaluate the carcass quantitative and qualitative characteristics of the shoulder and loin of Boer x Saanen crossbred goat kids, of both sexes, receiving a diet with live yeast (Saccharomyces cerevisiae var. boulardii).

\section{Materials and Methods}

This experiment was carried out in the goat farming sector at Iguatemi Experimental Farm, located in the Iguatemi district in Maringá, State of Paraná, Brazil. The care and manipulation of animals for the accomplishment of the experimental protocol was approved by the State University of Maringá Ethics Committee on the Use of Animals (Protocol 2217210519).

Twenty-seven Boer $x$ Saanen crossbred goat kids carcasses were used,
13 females and 14 uncastrated males (192 \pm 22 days of age and $30.76 \pm 1.73 \mathrm{~kg}$ of body weight). The animals were distributed in a completely randomised design in a $2 \times 2$ factorial arrangement of diet (without yeast and with yeast) and sex (female and male).

The base diet consisted of oat hay $(91.40 \% \mathrm{DM}, 10.98 \% \mathrm{CP}$ and $67.15 \%$ NDF), ground corn, soybean meal, mineral supplement and ammonium chloride. The diet was formulated to offer $70 \%$ total digestible nutrients (TDN) and 16\% CP. The complete mixed feed was pelleted to avoid animal selection and ensure homogeneous intake. The live yeast was added to the mixture in the amount of $0.050 \mathrm{~g} \mathrm{~kg}^{-1}$ of DM, and each animal was expected to ingest this daily amount of probiotic. The live yeast used was Saccharomyces cerevisiae var. boulardii I-1079, offered through Levucel| ${ }^{\circledR}$ SB $10 \mathrm{ME}$ TITAN (1.0 x 109 CFU/g concentration).

The diet was supplied according to the live weight of the animals. Every morning at 8 $h$, the refused rations were removed, weighed and noted. Diet supply was adjusted weekly to obtain approximately $10 \%$ refusals.

When the animals reached an average body weight of $30 \mathrm{~kg}$, they were fasted from solids (16h), and then weighed before slaughter to obtain the body weight at slaughter (BWS). The goat kids were slaughtered under Municipal Sanitary Inspection, according to the technical regulation of humanitarian slaughter of Brazil Normative Instruction $n^{\circ} 3$ of 2000 (Ministério da Agricultura, Pecuária e Abastecimento Brasil [MAPA], 2000).

Three days of slaughter were performed, as the animals reached the established mean body weight. In the first, nine animals were slaughtered, five on the control diet and four on live yeast. On a second day, 
five goat kids slaughtered, two were on the control diet and three on live yeast. And on the last day, 13 animals were slaughtered, where six belonged to the control diet and seven to live yeast supplementation.

The animals were stunned using an electrical shock of 220 volts for 8 seconds, bled by sectioning the jugular veins and carotid arteries, skinned and eviscerated. During evisceration, the gastrointestinal tract was emptied to determine the empty body weight (EBW: body weight at slaughter gastrointestinal tract content).

After carcass separation and nonconstituent of carcasses, the carcasses were weighed to obtain the hot carcass weight $(\mathrm{HCW})$ and to determine the true carcass yield $(\mathrm{TCY}=(\mathrm{HCW} / \mathrm{EBW}) \times 100)$. Subsequently, the carcasses were hung by the calcaneal tendon on appropriate hooks for maintaining the tarsometatarsal joints spaced at $17 \mathrm{~cm}$ and $\mathrm{pH}$ measurement ( $\left.\mathrm{pH} 45^{\prime}\right)$. At the end of the slaughter, the carcasses were covered with plastic bags and transported to a cold room at $4{ }^{\circ} \mathrm{C}$ for $24 \mathrm{~h}$.

After cooling for $24 \mathrm{~h}$, the $\mathrm{pH}$ was measured again ( $\mathrm{pH} 24 \mathrm{~h}$ ) and the carcasses were weighed, getting the cold carcass weight (CCW) to calculate the percentage of weight loss by cooling (WLC $=[(\mathrm{HCW}-\mathrm{CCW})$ / HCW x 100]) and carcass commercial yield $(\mathrm{CCY}=(\mathrm{CCW} / \mathrm{HCW}) \times 100)$, according to the methodology of Cezar and Sousa (2007).

Then, with the aid of a tape measure and a wooden compass, the leg length $(\mathrm{LL})$, the internal carcass length (ICL) and the width of the croup (WC) are measured. Through these measurements, the carcass compactness index $(\mathrm{CCl}=\mathrm{CCW} / \mathrm{ICL})$ and the leg compactness index ( $\mathrm{LCl}=\mathrm{WC} / \mathrm{LL})$ could be determined.
After the CCW, the tail was removed from the carcass and weighed individually, then the carcasses were cut longitudinally, and the left half of each one was divided into five anatomical regions or commercial cuts: leg, loin, rib, shoulder and neck. Each cut was weighed separately and then the cut yield was determined by the relationship between the cut weight and the half carcass weight.

In sequence, the Longissimus lumborum limits were realised (between the last thoracic vertebrae and the first lumbar, the loin) on the transversal cut of the muscle, with a transparent plastic blade appropriate pen. The loin eye area (LEA) was measured using the $A U T O C A D^{\circledR}$ computer program.

Additionally, four measurements on the Longissimus lumborum muscle were taken using a digital caliper: measure A: large length of the muscle; measure $B$ : short length of the muscle; measure $\mathrm{C}$ : short fat thickness over the muscle transversal section, continuation of axis $\mathrm{B}$; measure $\mathrm{J}$ : maximum fat thickness covering the loin in the profile.

The loin and the shoulder, both on the left half of the carcasses, were collected, packed in plastic containers and stored in a freezer until further analyses. For dissection and centesimal composition, the shoulder and loin were thawed at room temperature for 16 $\mathrm{h}$, and then dissected into muscle, bone and fat proportions, according to the methodology described by Sañudo and Sierra (1986). After dissection, the muscles were ground in a processor, homogenised and stored in a freezer for subsequent analysis.

The samples were thawed at room temperature for $24 \mathrm{~h}$, then dried at $55^{\circ} \mathrm{C}$ for 72 $\mathrm{h}$ and ground in a ball mill. The samples were analysed, in duplicate, for moisture (method 
950.15), ash (method 942.05), crude protein (CP, method of Kjeldahl 984.13) and lipids (method 920.39), according to Association of Official Analytical Chemists [AOAC] (2000).

Statistical analysis was performed using the Statistical Analysis System (version 9.0, SAS Institute Inc., Cary, NC) software. Means were compared by the Tukey test, using the probability level $(P<0.05)$, according to the following model:

$$
Y_{i j k}=\mu+R_{i}+S_{j}+e_{i j k}
$$

Where: $Y_{i j k}=$ characteristic observed in animal $\mathrm{k}$, receiving diet ${ }_{i}$, belonging to $\operatorname{sex}_{j} ; \mu=$ general constant; $\mathrm{R}_{i}=$ effect of dieti, where ${ }_{i}=1$ : control and 2: yeast; $\mathrm{S}_{j}=$ effect of sex $_{j}$, where $\mathrm{j}=1$ : female and 2: male; $e_{i j k}=$ random error associated with each $\mathrm{Y}_{i j k}$ observation.

\section{Results and Discussion}

Boer $x$ Saanen crossbred goat kids carcasses were not influenced by the addition of live yeast in the diet, but showed sex differences for BWS and AS, EBW, HCW, CCW, WLC and CCl (Table 1). Males were slaughtered with an average of $31.73 \mathrm{~kg}$ and 176 days of age. However, females, to reach the proposed weight of $30 \mathrm{~kg}$, remained in confinement 30 days longer than males. Since the measurements of EBW, HCW and CCW are directly related to the final weight of the animals, the males also presented higher values, being $27.97 \mathrm{~kg}, 14.39 \mathrm{~kg}$ and $14.22 \mathrm{~kg}$, respectively (Table 1). The higher productive performance of males may be caused by hormonal factors, which result in body development (Gomes et al., 2011).

\section{Table 1}

Slaughter age and quantitative carcass characteristics of crossbreed goat kids as a function of diet and sex

\begin{tabular}{|c|c|c|c|c|}
\hline \multirow{2}{*}{ Variables } & \multicolumn{2}{|c|}{ Diet } & \multicolumn{2}{|c|}{ Sex } \\
\hline & Control & Yeast & Female & Male \\
\hline AS (days) & $188.69 \pm 6.87$ & $193.86 \pm 5.88$ & $207.54 \pm 5.02 a$ & $176.36 \pm 4.29 b$ \\
\hline DC (days) & $94.77 \pm 6.42$ & $97.64 \pm 5.88$ & $111.92 \pm 4.23 a$ & $81.71 \pm 4.60 b$ \\
\hline BWS (kg) & $30.75 \pm 0.44$ & $30.98 \pm 0.49$ & $29.94 \pm 0.49 b$ & $31.73 \pm 0.27 a$ \\
\hline EBW (kg) & $26.99 \pm 0.52$ & $27.07 \pm 0.41$ & $26.01 \pm 0.43 b$ & $27.98 \pm 0.31 a$ \\
\hline HCW (kg) & $13.69 \pm 0.27$ & $14.10 \pm 0.23$ & $13.38 \pm 0.24 b$ & $14.39 \pm 0.18 a$ \\
\hline CCW (kg) & $13.48 \pm 0.29$ & $13.84 \pm 0.24$ & $13.07 \pm 0.24 b$ & $14.22 \pm 0.19 a$ \\
\hline CCY (\%) & $43.84 \pm 0.56$ & $44.66 \pm 0.33$ & $43.68 \pm 0.44$ & $44.81 \pm 0.43$ \\
\hline TCY (\%) & $50.77 \pm 0.51$ & $52.07 \pm 0.34$ & $51.44 \pm 0.44$ & $51.45 \pm 0.48$ \\
\hline WLC (\%) & $1.55 \pm 0.25$ & $1.86 \pm 0.36$ & $2.26 \pm 0.36 a$ & $1.20 \pm 0.19 b$ \\
\hline $\mathrm{pH} 45^{\prime}$ & $6.45 \pm 0.06$ & $6.43 \pm 0.07$ & $6.37 \pm 0.06$ & $6.51 \pm 0.06$ \\
\hline $\mathrm{pH} 24 \mathrm{~h}$ & $5.73 \pm 0.05$ & $5.73 \pm 0.06$ & $5.68 \pm 0.04$ & $5.78 \pm 0.06$ \\
\hline $\mathrm{CCl}(\mathrm{kg} / \mathrm{cm})$ & $0.27 \pm 0.00$ & $0.28 \pm 0.01$ & $0.27 \pm 0.01 b$ & $0.28 \pm 0.00 a$ \\
\hline $\mathrm{LCl}(\mathrm{kg} / \mathrm{cm})$ & $0.63 \pm 0.01$ & $0.65 \pm 0.01$ & $0.64 \pm 0.01$ & $0.65 \pm 0.01$ \\
\hline
\end{tabular}

$\mathrm{AS}=$ age at slaughter; $\mathrm{DC}=$ days in confinement; $\mathrm{BWS}=$ body weight at slaughter; $\mathrm{EBW}=$ empty body weight; $\mathrm{HCW}$ = hot carcass weight; $\mathrm{CCW}=$ cold carcass weight; $\mathrm{CCY}=$ commercial carcass yield; $\mathrm{TCY}=$ true carcass yield; WLC = weight loss by cooling; $\mathrm{pH} 45^{\prime}=$ carcass $\mathrm{pH}$ after $45 \mathrm{~min}$ at slaughter; $\mathrm{pH} 24 \mathrm{~h}=$ carcass $\mathrm{pH}$ after $24 \mathrm{~h} ; \mathrm{CCl}=$ carcass compactness index; $\mathrm{LCl}=$ leg compactness index. Means accompanied by letters on the same line differ $(\mathrm{P}<0.05)$ by the Tukey test. 
There was no effect of treatments on TCY, with averages of $51.44 \%$ and $44.26 \%$ for TCY and CCY, respectively (Table 1). Carcass yield is an important determinant of meat production potential, as the carcass is composed mainly of muscle, bone and fat (Guerrero, Campo, Olleta, \& Sañudo, 2018). In the present study, the values obtained for TCY and CCY corroborated with other studies (Freitas et al., 2011; Salles et al., 2013; Cartaxo et al., 2014).

WLC was influenced by sex, where male values (1.20\%) were lower than females (2.26\%). These results were lower and better than those observed in the carcasses of crossbred Boer goats of $3.03 \%$ by Dias, Silveira, Lançanova, Hill and Moletta (2016). Muscle surface moisture losses during carcass cooling are mainly dependent on fat coverage, due to the greater protection afforded to the carcass (Goetsch, Merkel, \& Gipson, 2011).

Carcass $\mathrm{pH}$ was not influenced by treatments, with average values of 6.44 after $45 \mathrm{~min}$ and 5.73 after $24 \mathrm{~h}$ in a cold room. The drop in $\mathrm{pH}$ after death is the result of post-mortem chemical reactions, considered an important factor in the transformation of muscle into meat, which directly influences the quality of the final product (Pophiwa et al., 2020). If the glycogen reserve is at adequate levels ensuring the $\mathrm{pH}$ drop, it will promote final $\mathrm{pH}$ values around 5.5 after $24 \mathrm{~h}$, not compromising the meat color characteristic. The $\mathrm{pH}$ drop was verified in the present study therefore it did not affect the carcass quality.

The sex influenced $\mathrm{CCl}$, whose values for males $\left(0.28 \mathrm{~kg} \mathrm{~cm}^{-1}\right)$ were higher than females $\left(0.27 \mathrm{~kg} \mathrm{~cm}^{-1}\right)$, demonstrating a larger amount of tissue per cm of carcass. However, the $\mathrm{LCl}$ did not differ between treatments and averaged $0.65 \mathrm{~kg} \mathrm{~cm}^{-1}$ (Table 1). The $\mathrm{CCl}$ values obtained were higher than those reported in the literature for Boer crossbred goats, ranging from 0.18 to $0.26 \mathrm{~kg} \mathrm{~cm}^{-1}$ (Dias et al., 2016; Salles et al., 2013). The LCl was inferior to that observed by Salles et al. (2013), with a range from 0.41 to $0.44 \mathrm{~kg} \mathrm{~cm}^{-1}$. These differences observed for compactness indices may be related to age and slaughter body weight, as well as the blood degree of the goat breed used. In addition, higher values of these indices are expected because they are related to the carcass muscularity (Salles et al., 2013).

There were no differences between the diets for the proportion and yield of commercial carcass cuts. However, males presented a higher weight of cuts for the shoulder, neck and ribs. For yields, there was a higher proportion of loin for females and a greater proportion of neck for males (Table 2). 


\section{Table 2}

Means of proportion and yield of commercial cuts, followed by standard error, of crossbreed goat kids (Boer $x$ Saanen) as a function of diet and sex

\begin{tabular}{|c|c|c|c|c|}
\hline \multirow{2}{*}{ Variables } & \multicolumn{2}{|c|}{ Diet } & \multicolumn{2}{|c|}{ Sex } \\
\hline & Control & Yeast & Female & Male \\
\hline \multicolumn{5}{|c|}{ Weight in kg of half-carcass cuts } \\
\hline Shoulder & $1.50 \pm 0.03$ & $1.52 \pm 0.03$ & $1.43 \pm 0.02 b$ & $1.58 \pm 0.02 \mathrm{a}$ \\
\hline Neck & $0.43 \pm 0.03$ & $0.41 \pm 0.02$ & $0.36 \pm 0.01 \mathrm{~b}$ & $0.48 \pm 0.02 \mathrm{a}$ \\
\hline Leg & $2.19 \pm 0.05$ & $2.29 \pm 0.05$ & $2.20 \pm 0.06$ & $2.27 \pm 0.05$ \\
\hline Rib & $1.87 \pm 0.05$ & $1.91 \pm 0.03$ & $1.80 \pm 0.04 b$ & $1.97 \pm 0.03 a$ \\
\hline Loin & $0.68 \pm 0.03$ & $0.75 \pm 0.02$ & $0.75 \pm 0.02$ & $0.68 \pm 0.03$ \\
\hline \multicolumn{5}{|c|}{ Percentage of cuts relative to half-carcass } \\
\hline Shoulder & $22.59 \pm 0.26$ & $22.05 \pm 0.25$ & $21.95 \pm 0.28$ & $22.64 \pm 0.21$ \\
\hline Neck & $6.40 \pm 0.34$ & $5.97 \pm 0.22$ & $5.47 \pm 0.17 b$ & $6.84 \pm 0.25 a$ \\
\hline Leg & $33.05 \pm 0.47$ & $33.23 \pm 0.50$ & $33.80 \pm 0.54$ & $32.53 \pm 0.36$ \\
\hline Rib & $28.14 \pm 0.55$ & $27.77 \pm 0.45$ & $27.58 \pm 0.48$ & $28.29 \pm 0.50$ \\
\hline Loin & $10.33 \pm 0.50$ & $10.90 \pm 0.41$ & $11.55 \pm 0.43 a$ & $9.77 \pm 0.36 b$ \\
\hline
\end{tabular}

Means accompanied by letters on the same line differ $(\mathrm{P}<0.05)$ by the Tukey test.

Changes in yield of commercial cuts are often related to changes in growth rates, maturity, age, genotype and sex (Ferraz, Guim, Véras, Carvalho, \& Freitas, 2018). The higher carcass weights observed for males, except for the loin, are explained by the sexual dimorphism existing between the sexes along their body development. Males have higher muscle growth potential, consequently higher muscle deposition in the carcass compared to females, which can be explained by genetic and hormonal factors (Gomes et al., 2011).

The average yield of shoulder and rib cuts were $22.31 \%$ and $27.94 \%$, respectively, and together they account for $50.25 \%$ of the carcass cuts (Table 2). Regarding neck development, higher yields were observed for males $(6.84 \%)$, while the highest yield of loin were observed for females (11.55\%).
Partition of carcass cuts facilitates commercialisation and adds value by differentiating cuts. The highest commercial value cuts of goat carcasses are leg, shoulder and loin, and the yield of these cuts in relation to carcass is in the range of $26.4 \%$ to $33.6 \%$ for the leg, $9.5 \%$ to $13.6 \%$ for the loin, and $17.9 \%$ to $25.7 \%$ for the shoulder (Guerrero et al., 2018).

The leg represents the highest carcass yield, since it is where the largest muscle masses are, representing the noblest meat cut in small ruminants (Marques et al., 2013), therefore, it should present high yields. In this study, the average obtained for the leg yield was $33.17 \%$ (Table 2). However, Carvalho, Pereira, Silva, Silva and Cesar (2011), observed in $1 / 2$ Boer-NDB goat carcasses that leg yield was $30.22 \%$, which indicates how crosses can result in different muscle proportions. 
The shoulder and the rib are the cuts with intermediate appreciation among cuts as because they have a lower proportion of muscle tissue when compared to the leg and loin. The neck is the goatmeat cut of lower added value in commercialisation as it has little distribution of muscular mass. In this work, males showed higher performance in relation to neck development (Table 2).

Females had higher loin yield (Table 2), which can be attributed to the anatomical development of the posterior region in females. According to Gomes et al. (2011), females an anatomical advantage in the development of this region, due to growth characteristics of parts associated with childbirth.

Evaluating Boer x NDB kids, Cartaxo et al. (2014) observed an average of $28.28 \%$ for leg yield, $12.42 \%$ for loin, $20.56 \%$ for shoulder, $27.13 \%$ for rib and $7.05 \%$ for neck. From a commercial point of view, the sum of neck and rib yields should not exceed those of the leg and loin, and the shoulder, as they have lower commercial value and are not considered noble parts of the carcass, which is in agreement with the values obtained (Table $2)$, being higher of the leg and loin (43.83\%) in relation to the yield of the shoulder $(22.30 \%)$ and that of the ribs with the neck (34.08\%).

The inclusion of live yeast in the diet did not influence the chemical composition and bone, muscle and fat proportions of the Boer x Saanen goat kids shoulder. Regarding sex, males had higher bone proportions, and females had higher fat and muscle:bone ratio (Table 3).

\section{Table 3}

Centesimal composition, percentage of bone, muscle and fat, and muscle: bone ratio of shoulder of crossbreed goat kids as a function of diet and sex

\begin{tabular}{|cccccc} 
Variables & \multicolumn{2}{c}{ Diet } & \multicolumn{2}{c}{ Sex } \\
\cline { 5 - 6 } \cline { 5 - 6 } Moisture (\%) & Control & Yeast & & Female & Male \\
\hline Ash (\%) & $0.97 \pm 0.03$ & $76.07 \pm 0.35$ & & $76.27 \pm 0.36$ & $75.99 \pm 0.57$ \\
\hline Protein (\%) & $20.78 \pm 0.54$ & $21.00 \pm 0.32$ & & $20.51 \pm 0.28$ & $21.25 \pm 0.52$ \\
\hline Lipid (\%) & $3.41 \pm 0.11$ & $3.23 \pm 0.12$ & & $3.32 \pm 0.13$ & $3.32 \pm 0.11$ \\
\hline Bone (\%) & $17.89 \pm 0.35$ & $17.60 \pm 0.50$ & & $16.84 \pm 0.37 \mathrm{~b}$ & $18.58 \pm 0.36 \mathrm{a}$ \\
Muscle (\%) & $57.63 \pm 0.68$ & $57.79 \pm 0.67$ & & $58.04 \pm 0.86$ & $57.41 \pm 0.46$ \\
Fat (\%) & $16.10 \pm 0.61$ & $16.03 \pm 0.66$ & & $17.09 \pm 0.71 \mathrm{a}$ & $15.11 \pm 0.41 \mathrm{~b}$ \\
\hline Muscle:Bone & $3.24 \pm 0.08$ & $3.32 \pm 0.12$ & & $3.47 \pm 0.10 \mathrm{a}$ & $3.11 \pm 0.08 \mathrm{~b}$ \\
\hline
\end{tabular}

Means accompanied by letters on the same line differ $(P<0.05)$ by the Tukey test. 
The centesimal composition of the Longissimus lumborum muscle performed by Marques et al. (2013) observed averages of $76.25 \%$ moisture, $1.07 \%$ ash, $21.04 \%$ protein and $2.30 \%$ total lipids. These averages were similar to the results obtained in this study.

The sex is a factor that influences the proportion of tissue deposition and the commercial quality of carcass, as females naturally have greater fat deposition than males (Guerrero et al., 2018). Due to physiological characteristics, uncastrated male animals have higher muscle content than females (Gomes et al., 2011).

Regarding the proportions of the tissues in relation to sex, a higher proportion of fat was observed for females (17.09\%) compared to males $(15.11 \%)$, corresponding to a difference of $11.59 \%$ between sexes. For the proportion of bone, males presented higher values (18.58\%), consequently, the muscle:bone ratio for males was lower (3.11) compared to females (3.47).
For the proportions of the muscle, bone and fat of the goat kids' loin, similarity was observed to studies by Marques et al. (2013) and Salles et al. (2013), whose values ranged from $56.52 \%$ to $68.26 \%$ for muscle yield, $15.23 \%$ to $19.34 \%$ for bone yield and $12.39 \%$ to $26.68 \%$ for fat yield. The proportion of bones observed in the present study was lower than the values found by Freitas et al. (2011) who observed a muscle: bone ratio of $6.13 \%$ for Saanen animals and $7.40 \%$ for Boer $x$ Saanen animals.

There was no influence of live yeast on the chemical composition and on the bone, muscle and fat proportions of the Longissimus lumborum muscle. However, regarding sex, a higher percentage of fat was observed for females (Table 4). The approximate composition of the Longissimus lumborum muscle showed an average of $76.13 \%$ moisture, $0.91 \%$ ash, $19.68 \%$ protein and $3.04 \%$ total lipids, showing small variations in protein and fat.

\section{Table 4}

Centesimal composition, percentage of bone, muscle and fat, and muscle: bone ratio of crossbreed goat kids loin as a function of diet and sex

\begin{tabular}{|cccccc} 
Variables & \multicolumn{2}{c}{ Diet } & & \multicolumn{2}{c}{ Sex } \\
\cline { 2 - 3 } \cline { 5 - 6 } Moisture (\%) & $76.19 \pm 0.61$ & $76.07 \pm 0.35$ & & $76.27 \pm 0.36$ & $75.99 \pm 0.57$ \\
Ash (\%) & $0.90 \pm 0.01$ & $0.91 \pm 0.02$ & & $0.92 \pm 0.01$ & $0.90 \pm 0.02$ \\
Protein (\%) & $19.50 \pm 0.19$ & $19.84 \pm 0.19$ & & $19.83 \pm 0.16$ & $19.53 \pm 0.22$ \\
Lipid (\%) & $3.02 \pm 0.15$ & $3.05 \pm 0.16$ & & $3.16 \pm 0.12$ & $2.91 \pm 0.18$ \\
Bone (\%) & $16.54 \pm 0.92$ & $16.79 \pm 1.27$ & & $15.89 \pm 0.91$ & $17.40 \pm 1.25$ \\
Muscle (\%) & $61.22 \pm 1.54$ & $63.36 \pm 1.10$ & & $62.19 \pm 1.48$ & $62.46 \pm 1.24$ \\
Fat (\%) & $18.63 \pm 0.88$ & $16.89 \pm 0.85$ & & $19.54 \pm 0.83 \mathrm{a}$ & $16.05 \pm 0.67 \mathrm{~b}$ \\
Muscle:Bone & $3.92 \pm 0.34$ & $4.12 \pm 0.38$ & & $4.15 \pm 0.36$ & $3.91 \pm 0.36$ \\
\hline
\end{tabular}

Means accompanied by letters on the same line differ $(P<0.05)$ by the Tukey test. 
Concerning the proportions of tissues in relation to sex, a higher proportion of adipose was observed for females. Due to the high proportion of bone observed, the muscle: bone ratio presented an average of $4.03 \%$ (Table 4). No treatment effects were observed on LEA, measure $A$, measure $B$, measure $C$, and measure $\mathrm{J}$ (Table 5).

\section{Table 5}

Measurements of Longissimus lumborum muscle of crossbred goat kids as a function of diet and sex

\begin{tabular}{cccccc}
\multirow{2}{*}{ Variables } & \multicolumn{2}{c}{ Diet } & \multicolumn{2}{c}{ Sex } \\
\cline { 5 - 6 } \cline { 5 - 6 } & Control & Yeast & & Female & Male \\
\hline LEA $\left(\mathrm{cm}^{2}\right)$ & $13.91 \pm 0.56$ & $14.55 \pm 0.50$ & & $13.88 \pm 0.64$ & $14.58 \pm 0.42$ \\
Measure $\mathrm{A}(\mathrm{mm})$ & $54.83 \pm 1.30$ & $54.72 \pm 1.37$ & & $53.78 \pm 1.35$ & $55.70 \pm 1.27$ \\
Measure $\mathrm{B}(\mathrm{mm})$ & $25.33 \pm 0.78$ & $26.57 \pm 0.59$ & & $25.71 \pm 0.82$ & $26.22 \pm 0.58$ \\
Measure $\mathrm{C}(\mathrm{mm})$ & $0.76 \pm 0.05$ & $0.82 \pm 00.04$ & & $0.84 \pm 0.04$ & $0.74 \pm 0.04$ \\
Measure $\mathrm{J}(\mathrm{mm})$ & $1.00 \pm 0.04$ & $1.12 \pm 0.06$ & & $1.12 \pm 0.06$ & $1.01 \pm 0.04$
\end{tabular}

LEA = loin eye area; Measure $A=$ longer length; Measure $B=$ shorter length; Measure $C=$ fat thickness; Measure $\mathrm{J}=$ greater fat thickness.

The evaluation of the Longissimus lumborum or LEA is considered a measure associated with muscle development, as well as the quality of muscle mass. According to Grande et al. (2011), the measurements of the longest and shortest loin length serve to evaluate the amount of muscle in the carcass. As it is considered a late maturiting muscle, the measurements can be extrapolated for the whole carcass, being a practical evaluation to estimate the carcass muscle.

The measurements taken on the goat kids' loin were within those reported in previous studies with Boer crossbred goat kids (Cartaxo et al., 2014; Dias et al., 2016; Salles et al., 2013), ranging from $5.65 \mathrm{~cm}^{2}$ to 15.21 $\mathrm{cm}^{2}$ for LYA, $44.23 \mathrm{~mm}$ to $53.10 \mathrm{~mm}$ for larger length measurement, $22.74 \mathrm{~mm}$ to $26.30 \mathrm{~mm}$ for shorter length measurement, $0.86 \mathrm{~mm}$ to $1.55 \mathrm{~mm}$ for fat thickness measurement and $1.52 \mathrm{~mm}$ to $3.07 \mathrm{~mm}$ to measure the largest fat thickness. The increase in measurements for fat thickness is due to the fact that adipose tissue has increased growth at older ages.

\section{Conclusion}

The inclusion of live yeast (Saccharomyces cerevisiae var. boulardii) in the diet of confined crossbred Boer $x$ Saanen goat kids did not influence the quantitative carcass characteristics and the qualitative characteristics of the shoulder and loin.

\section{Acknowledgments}

The authors are grateful to the Brazilian institutions and research agencies CAPES and CNPq, and the Lallemand Animal Nutrition (supply of Saccharomyces cerevisiae var. boulardii). 


\section{Conflict of interest statement}

The authors declared no conflicts of interest.

\section{References}

Association of Official Analytical Chemists (2000). Official methods of analysis of Association of Official Analytical Chemists (17nd ed.). Gaithersburg, EUA: AOAC.

Cartaxo, F. Q., Sousa, W. H., Leite, M. L. D. M. V., Cezar, M. F., Cunha, M. D. G. G., Viana, J. A.,... Cabral, H. B. (2014). Carcass traits of goat kids from different genotypes finished in feedlot. Revista Brasileira de Saúde e Produção Animal, 15(1), 120-140. doi: 10. 1590/S1519-99402014000100019

Carvalho, A. M., Jr., Pereira, J. M., Fo., Silva, R. M., Silva, M. A. A., \& Cesar, M. F. (2011). Effect of supplementation on the performance of $\mathrm{F} 1$ crossbred goats finished in native pasture. Revista Brasileira de Zootecnia, 4O(11), 2510-2517. doi: 10.1590/S151635982011001100032

Cezar, M. F., \& Sousa, W. H. (2007). Carcaças ovinas e caprinas: obtenção, avaliação e comercialização. Uberaba: Agropecuária Tropical.

Dias, J. C., Silveira, A. L. F., Lançanova, J. A. C., Hill, J. A., \& Moletta, J. L. (2016). Crude glycerin in meat goat diets: intake, performance and carcass traits. Ciência Rural, 46(4), 719-724. doi: 10.1590/0103$8478 c r 20141489$

Ferraz, V. L., Guim, A., Véras, R. M. L., Carvalho, F. F. R. C., \& Freitas, M. T. D. (2018). Cassava dreg as replacement of corn in goat kid diets. Tropical Animal Health and
Production, 50(2), 309-315. doi: 10. 1007/ s11250-017-1432-3

Freitas, H. S., Alcalde, C. R., Lima, L. S., Macedo, F. A. F., Macedo, V. P., \& Molina, B. S. L. (2011). Quantitative characteristics of carcass and meat quality of $3 / 4$ Boer+ $1 / 4$ Saanen and Saanen goat kids fed diets with dry yeast. Revista Brasileira de Zootecnia, 40(3), 630-638. doi: 10.1590/ S1516-3598201100 0300023

Goetsch, A. L., Merkel, R. C., \& Gipson, T. A. (2011). Factors affecting goat meat production and quality. Small Ruminant Research, 101(1-3), 173-181. doi: 10.10 16/j.smallrumres.2011.09.037

Gomes, H. F. B., Menezes, J. J. L., Gonçalves, H. C., Cañizares, G. I. L., Medeiros, B. B. L., Polizel, A. Neto,... Chávari, A. C. T. (2011). Carcass traits of characteristics of kid goats from five breed groups raised in a feedlot system. Revista Brasileira de Zootecnia, 40(2), 411-417. doi: 10.1590/ S1516-3598 2011000200024

Grande, P. A., Alcalde, C. R., Lima, L. S., Macedo, V. P., Macedo, F. A. F., \& Matsushita, M. (2011). Carcass evaluation of Saanen kids fed oilseeds diets. Arquivo Brasileiro de Medicina Veterinária e Zootecnia, 63(3), 721-728. doi: 10.1590/S0102-093 52011000300025

Guerrero, A., Campo, M. M., Olleta, J. L., \& Sañudo, C. (2018). Carcass and meat quality in goat. In S. Kukovics (Ed.), Goat science (pp. 267-286). London: IntechOpen.

Kayser, W. C., Carstens, G. E., Parsons, I. L., Welsh, T. H., Washburn, K. E., Lawhon, S. D., ... Skidmore, A. L. (2019). Effects of Mannheimia haemolytica challenge 
with or without supplementation of Saccharomyces cerevisiae boulardii strain CNCM I-1079 on immune upregulation and behavior in beef steers. Journal of Animal Science, 97(2), 596-609. doi: 10.1093/jas/sky447

Liotta, L., Chiofalo, V., Lo Presti, V., \& Chiofalo, B. (2020). Effect of production system on growth performances and meat traits of suckling Messinese goat kids. Italian Journal of Animal Science, 19(1), 245-252. doi: 10.1080/1828051X.2020.1726832

Marques, R. O., Menezes, J. J. L., Gonçalves, H. C., Medeiros, B. B. L., Rodrigues, L., Cañizares,... Roça, R. O. (2013). Cut yields, carcass and tissue composition proportion in meat from young goats depending on the breed and slaughter body weight. Arquivo Brasileiro de Medicina Veterinária e Zootecnia, 65(5), 1561-1569. doi: 10.1590/S0102-093520 13000500038

Ministério da Agricultura, Pecuária e Abastecimento 2000. Instrução Normativa $\mathrm{n}^{0} 3$, de 17 de Janeiro de 2000. Aprova o regulamento técnico de métodos de insensibilização para o abate humanitário de animais de açougue. Diário Oficial da União, Brasília. Recuperado de https://www.gov.br/agricultura/pt-br/ assuntos/sustentabilidade/bem-estaranimal/arquivos/arquivos-legislacao/in03-de-2000.pdf/view
Pophiwa, P., Webb, E. C., \& Frylinck, L. (2020). A review of factors affecting goat meat quality and mitigating strategies. Small Ruminant Research, 183, 106035. doi: 10. 1016/j.smallrumres.2019.106035

Rai, V., Yadav, B., \& Lakhani, G. P. (2013). Application of probiotic and prebiotic in animals production: a Review. Environment \& Ecology, 31(2B), 873-876.

Salles, F. M., Zambom, M. A., Alcalde, C. R., Macedo, F. A. F., Souza, R., Gomes, L. C., ... Molina, B. S. L. (2013). Carcass characteristics of goat kids in two finishing systems. Arquivo Brasileiro de Medicina Veterinária e Zootecnia, 65(6), 1867-1875. doi: 10.1590/S0102-093520 13000600039

Sañudo, C., \& Sierra, I. (1986). Calidad de la canal em la especie ovina. In C. B. Carbó (Ed.), Vino (pp. 127-157). Barcelona, Espanha: One S.A.

Uyeno, E., Shigemori, S., \& Shimosato, T. (2015). Effect of probiotics/prebiotics on cattle health and productivity. Microbes and Environments, 30(2), 126-132. doi: 10.1264/jsme2.ME14176 